\title{
AGRICULTURAL ENTERPRISES PRODUCTION EVALUATION AND DEVELOPMENT IN UKRAINE
}

\author{
Serhiy US ${ }^{1}$ \\ National University of Life and Environmental Sciences of Ukraine, Ukraine
}

\begin{abstract}
The purpose of the article is to analyze correlation between production volume $(\mathrm{V})$, labour factor $(\mathrm{L})$ and capital factor (K) with further production volume forecasting of researched agricultural enterprises in Ukraine as well as their competitiveness in the European market. Methodology. The survey based on statistical data of State statistics service in Ukraine, Poland and accounting data of investigated enterprises during 2004-2013 years. Production volume and capital amount taken in monetary terms, labour factor is calculated in monetary terms using the average wage and the number of employees. Treatment of major production factors according to classical economic theory is generalized. Correlation of $\mathrm{V}, \mathrm{L}$ and $\mathrm{K}$ factors are calculated using method of the least squares in production function evaluation. Production volume of enterprises $A$ and $B$ are forecasted with further evaluation of its reliability in the econometric program EViews 7. Results of the survey showed the dominant role of $\mathrm{L}$ factor over the $\mathrm{K}$ factor especially after world economic crisis 2008 in investigated agricultural enterprises of Ukraine. According to high determination coefficient, the influence of both factors on production volume is $85 \%$ for enterprise A and 95\% for enterprise B. Production forecast shows the increase of its volume till 2020 in both enterprises with high probability according to forecast credibility indicator MAPE. Practical implications. Application of the results, in particular the ratio of production factors and forecast of production volume, will allow more effective use of production resources and better planning of production process taking into account market conditions. Value/originality. Production activity estimation and output forecast of investigated agricultural enterprises were used for competitiveness analysis of agricultural enterprises in Ukraine and Poland, which is important for European integration process of domestic economy.
\end{abstract}

Key words: production factors, agricultural enterprises, production forecast, production function, optimization.

JEL Classification: Q12, B12, D24, C53

\section{Introduction}

In the economic crisis conditions of Ukraine in 20142015 an effective usage of available resources, including labor and capital, through production optimization has become particularly important. According to classical economic theory, the desire of entrepreneurs to achieve their interests leads to economic benefits for society (Smith, 2012). This statement prove that effective production process in different organizations should be encouraged and achieved by choosing appropriate development strategy. In order to choose correct development strategy for agricultural enterprises, it is necessary to have deep understanding of processes and trends inside and outside of the enterprises. That required usable methodology and tools for comprehensive analysis taking into account the purpose of investigation. Using of the data of State statistics service in Ukraine, Poland and accounting data of investigated enterprises during 2004-2013 years production function built with further identification of production optimization possibility.
Moreover, econometric forecasting methods were used to find out production volume till 2020 and to identify the most effective production development strategy.

\section{Analysis of the main publications}

The basis of production process is about effective use of economic resources by converting to the production inputs. One of the main tasks of economics is to increase economic efficiency by optimizing these factors usage. This could be done by determination of effective ratio between inputs and intensity of their usage. In general, classic economic school distinguishes three factors of production: land, labour and capital, which are independent sources of value. Wages are the price of labour, profit is the result of capital, rent is a "gift of nature". At the same time capital refers to buildings, instruments, machinery, so called real capital (Say, 2012). One of the main methods to research technological ration between production factors and its volume is production function (Shepherd, 2015).

Corresponding author:

${ }^{1}$ Department of Agribusiness, National University of Life and Environmental Sciences of Ukraine.

E-mail: sergey.us.ua@gmail.com 
Capital as a factor of production represented by a set of previously manufactured benefits, which are involved in goods and services production process to: tools, machines, equipment, production facilities, communications etc. Their technical and technological condition constantly improving and has decisive impact on the economic activity. Labour presented as intellectual and physical activity focused on goods and services production. Also it's treated as "human capital", which means a combination of knowledge, skills and abilities of person due to education, professional training, skill, health etc. Complicated work leads to higher human capital and as a result the increase of income (Kundyzky, 2012). Individual and material factors are the complex system elements connected by technology and organization of production. Therefore, technology expresses cooperation between main production factors and means using of different processing factors, change of characteristics, form and conditions of labour subjects. Organization of production provides coherent functioning of all production factors, their ratio, interchangeability etc.

In the market economy the factors choice isn't accidental but has theoretical basis which gives meaningful interpretation of production function characteristics. Discussions about production factors and type of production function ratio given foundation for more general concept instead of production function production dependence which is defined as functional correlation more general type with possibility to use not only absolute but also relative values as well as wide set of non-traditional production factors. Among the methods that are offered by specialist for adequacy consideration of transitional economy specifics it is necessary to underline preliminary analysis of data before specified dependencies parameters evaluation. In other words, not just production function construction macroeconomic dynamics analyzing using terms and concepts from the theory of production function (Shumska, 2007).

\section{The influence of main production factors on its volume}

There are many useful tool which can be used to analyze internal and external environment of enterprise functioning. According to the purpose of the research, it's appropriate to use production function for analysis of production factors influence on its volume. Production function - is a technical ratio between amount of resources, which used by producers, and volume of output on this basis. Production function could be used at macroeconomic and microeconomic levels (Mocherny, 2005).

Among the most usable types of production function is Cobb-Douglas function, which in general can be written as (Shumska, 2007):

$$
\mathrm{Y}_{\mathrm{t}}=\mathrm{f}\left(\mathrm{K}_{\mathrm{t}}, \mathrm{L}_{\mathrm{t}}\right)=\mathrm{AK}_{\mathrm{t}}^{\alpha} \mathrm{L}_{\mathrm{t}}^{\beta}
$$

where $\mathrm{A}$ - coefficient which characterises production effectiveness, $\alpha$ i $\beta$ - coefficients of production elasticity of capital (K) and labour (L), which according to neoclassical theory reflects the role of every production factor in the surplus of final product (or relevant factor share of revenue in units of total income). In practical calculation model converted in log-linear and resulting equation becomes:

$$
\operatorname{LOG}(\mathrm{Y})=\mathrm{C}_{1} \operatorname{LOG}\left(\mathrm{X}_{1}\right)+\mathrm{C}_{2} \operatorname{LOG}\left(\mathrm{X}_{2}\right)+\mathrm{C}_{3} \text {. }
$$

A first, every constructed production function should pass actual logic and statistical adequacy check. Logic adequacy means equation compliance with the economic content of the investigated phenomenon. Statistical adequacy and reliability characterize by the system of indicators and its comparison with established limits.

In terms of European integration, agricultural enterprises of Ukraine should consider market conditions of countries in European Union. One of the main agricultural countries in European Union is Poland, which agricultural production was assessed for comparison with Ukraine.

Table 1

\begin{tabular}{|c|c|c|c|c|}
\hline \multicolumn{5}{|c|}{ Dependent Variable: LOG(V) } \\
\hline \multicolumn{5}{|l|}{ Method: Least Squares } \\
\hline \multicolumn{5}{|c|}{ Sample (adjusted): 20042013} \\
\hline \multicolumn{5}{|c|}{ Included observations: 10 after adjustments } \\
\hline \multicolumn{5}{|c|}{$\operatorname{LOG}(\mathrm{V})=\mathrm{C}(1) * \mathrm{LOG}(\mathrm{K})+\mathrm{C}(2)^{*} \mathrm{LOG}(\mathrm{L})+\mathrm{C}(3)$} \\
\hline Variable & Coefficient & Std. Error & $\mathrm{t}$-Statistic & Prob. \\
\hline LOG $(\mathrm{K})$ & 0.117018 & 0.156325 & 0.748555 & 0.0785 \\
\hline LOG $(\mathrm{L})$ & 0.739496 & 0.317872 & 2.326396 & 0.0529 \\
\hline $\mathrm{C}$ & 4.577633 & 0.895225 & 5.113390 & 0.0014 \\
\hline R-squared & 0.846017 & \multicolumn{2}{|c|}{ Mean dependent var } & 9.832381 \\
\hline Adjusted R-squared & 0.802022 & \multicolumn{2}{|c|}{ S.D. dependent var } & 0.582694 \\
\hline S.E. of regression & 0.259268 & \multicolumn{2}{|c|}{ Akaike info criterion } & 0.381418 \\
\hline Sum squared resid & 0.470540 & \multicolumn{2}{|c|}{ Schwarz criterion } & 0.472194 \\
\hline Log likelihood & 1.092909 & \multicolumn{2}{|c|}{ Hannan-Quinn criter. } & 0.281838 \\
\hline F-statistic & 19.22975 & \multicolumn{2}{|c|}{ Durbin-Watson stat } & 2.897791 \\
\hline Prob(F-statistic) & 0.001433 & & & \\
\hline
\end{tabular}

Evaluation of regression model parameters for enterprise $A$

Source: calculated by the author 
Following the terms of logical and statistical adequacy it was calculated that agricultural enterprises in Ukraine has $\mathrm{L}=0,39$ and $\mathrm{K}=0,88$ ratio of production factors while in Poland factors are $\mathrm{L}=0,20$ and $\mathrm{K}=2,28$ which means lower labour input and better effectiveness of agricultural enterprises in Poland. For better evaluation of agricultural enterprises production activity there were identified similar by size and production structure agricultural enterprises in Ukraine. The production function equation obtained for period 2004-2013 and estimated by method of least squares in econometric program EViews 7. Constructed regression models show correlation between outputs $(\mathrm{V})$, fixed assets $(\mathrm{K})$ and salary fund $(\mathrm{L})$. There is the following model for enterprise $\mathrm{A}$ :

LOG $(\mathrm{V})=0.117018009955^{*} \mathrm{LOG}(\mathrm{K})+$

$0.73949633459 *$ LOG $(\mathrm{L})+4.57763310322$.

Evaluation of enterprise A regression model is shown in a table. 1.

According to the calculation $\mathrm{R}^{2}=0,846$ (coefficient of determination), which means than change in production volume is caused on $85 \%$ by labour and capital factors. Criteria of Durbin-Watson (DW=2.897791) means presence of first order negative autocorrelation of regression model; statistical significance of results for $\mathrm{L}=0,05$ and $\mathrm{K}=0,08$ is high; Prob (F-statistic) $=0,001$ which means properly selected equation for calculation. Coefficients $\mathrm{L}=0,74$ and $\mathrm{K}=0,12$ which together is equal $0,86<1$ that means negative effect on scale, significant need of investments and dominant role of labour factor on production output. There is the following model for enterprise $\mathrm{B}$ :

LOG $(\mathrm{V})=0.478201119432 * \mathrm{LOG}(\mathrm{K})+$ $+0.851756603007^{*} \mathrm{LOG}(\mathrm{L})+0.961445526587$.

Evaluation of enterprise $B$ regression model is shown in a table. 2. According to the calculations change in production volume caused on $95 \%\left(\mathrm{R}^{2}=0.950181\right)$ by factors of capital and labour; DW=2.397459, which means presence of first order negative autocorrelation of regression model; statistical significance of results for $\mathrm{L}=0,03$ and $\mathrm{K}=0,00$ is high; Prob (F-statistic) $=0,000$, which means properly selected equation for calculation. The sum of labour coefficient $(\mathrm{L}=0,85)$ and capital coefficient $(\mathrm{K}=0,48)$ is $1,33>1$, which means high reproduction level with dominant role of labour factor. At the same time estimation of the regression model during 2004-2008 and 2009-2013 showed dominant role in both enterprises of capital factor before 2008 and conversion to labour factor since 2009 . That means reduce of access to financial resources because of the global economic crisis 2008 with compensation of it by an increase in use of labour resources.

Agricultural enterprises of Ukraine require investments in production process to improve production efficiency by optimizing labour costs. It is necessary to become competitive comparing with European producers. At the same time, for effective production process optimization in agricultural enterprises of Ukraine it's reasonable to forecast their production activity.

\section{Determination of production volume on prospect}

In order to ensure production effectiveness of agricultural enterprises and price stability on the agricultural products market it's appropriate to apply methods of market conditions forecasting. According to the purpose of the research, forecasts of investigated enterprises production volume were made. On the Fig. 1 there is a production volume forecast for enterprise A.

Using available statistic data with an assumption about production dynamics preserving agricultural production volume forecast was built for the enterprise A till 2020 with level reliability at $\mathrm{MAPE}=16,2$ which is sufficient level to be considered significant. According to a forecast, production

Table 2

Evaluation of regression model parameters for enterprise $B$

\begin{tabular}{|c|c|c|c|c|}
\hline \multicolumn{4}{|c|}{ Dependent Variable: LOG(V) } & \\
\hline \multicolumn{5}{|l|}{ Method: Least Squares } \\
\hline \multicolumn{5}{|c|}{ Sample (adjusted): 20042013} \\
\hline \multirow{2}{*}{\multicolumn{5}{|c|}{$\begin{array}{l}\text { Included observations: } 10 \text { after adjustments } \\
\mathrm{LOG}(\mathrm{V})=\mathrm{C}(1)^{*} \mathrm{LOG}(\mathrm{K})+\mathrm{C}(2)^{*} \mathrm{LOG}(\mathrm{L})+\mathrm{C}(3)\end{array}$}} \\
\hline & & & & \\
\hline Variable & Coefficient & Std. Error & $\mathrm{t}$-Statistic & Prob. \\
\hline LOG $(\mathrm{K})$ & 0.478201 & 0.454402 & 1.052375 & 0.0276 \\
\hline LOG(L) & 0.851757 & 0.113606 & 7.497494 & 0.0001 \\
\hline $\mathrm{C}$ & 0.961446 & 3.313660 & 0.290146 & 0.7801 \\
\hline R-squared & 0.950181 & Mean dependent var & 9.114894 & \\
\hline Adjusted R-squared & 0.935947 & S.D. dependent var & 0.520437 & \\
\hline S.E. of regression & 0.131716 & Akaike info criterion & -0.973013 & \\
\hline Sum squared resid & 0.121444 & Schwarz criterion & -0.882237 & \\
\hline Log likelihood & 7.865064 & Hannan-Quinn criter. & -1.072593 & \\
\hline F-statistic & 66.75420 & Durbin-Watson stat & 2.397459 & \\
\hline Prob(F-statistic) & 0.000028 & & & \\
\hline
\end{tabular}

Source: calculated by the author 
volume of agricultural enterprise A in 2020 will be 48245 thsd UAH. At the same time, this figure can change from 30930 thsd UAH to 75254 thsd UAH according to the calculation. Construct forecast for enterprise B using the same methodology (Fig. 2).

Forecast reliability for the enterprise $\mathrm{B}$ is higher than for the previous enterprise (MAPE=13,0). According to a forecast, production volume of agricultural enterprise $\mathrm{B}$ in 2020 will be 22061 thsd UAH. At the same time, this figure can change from 15354 thsd UAH to 31697 thsd $\mathrm{UAH}$ according to the calculation.

\section{Survey methodology}

The survey based on statistical data of State statistics service in Ukraine, Poland and accounting data of investigated enterprises during 2004-2013 years. Production volume and capital amount taken in monetary terms, labour factor is calculated in monetary terms using the average wage and the number of employees. Treatment of major production factors according to classical economic theory is generalized. Correlation of $\mathrm{V}, \mathrm{L}$ and $\mathrm{K}$ factors are calculated using method of the least squares in production function evaluation. Production volume of enterprises A and $B$ is forecasted with further evaluation of its reliability in the econometric program EViews 7.

\section{Conclusions}

According to the statements of classical economic theory, production factors include land, labour and capital. All of these factors are equally important for the production process. Research of the correlation between production volume, labour and capital can be done by using Cobb-Douglas production function. Research is shown that agricultural enterprises in Ukraine are less competitive then in Poland because of higher labour input and lower capital investments, for example, in Ukraine average enterprise has $L=0,39$ and $K=0,88$. At the same time in Poland these factors are $\mathrm{L}=0,20$ and $\mathrm{K}=2,28$. This situation requires increase of investment in fixed assets of agricultural enterprises and optimizing labour usage. Investigated agricultural enterprises $A$ and $B$ have worse ratio of production factors than the average in Ukraine. For

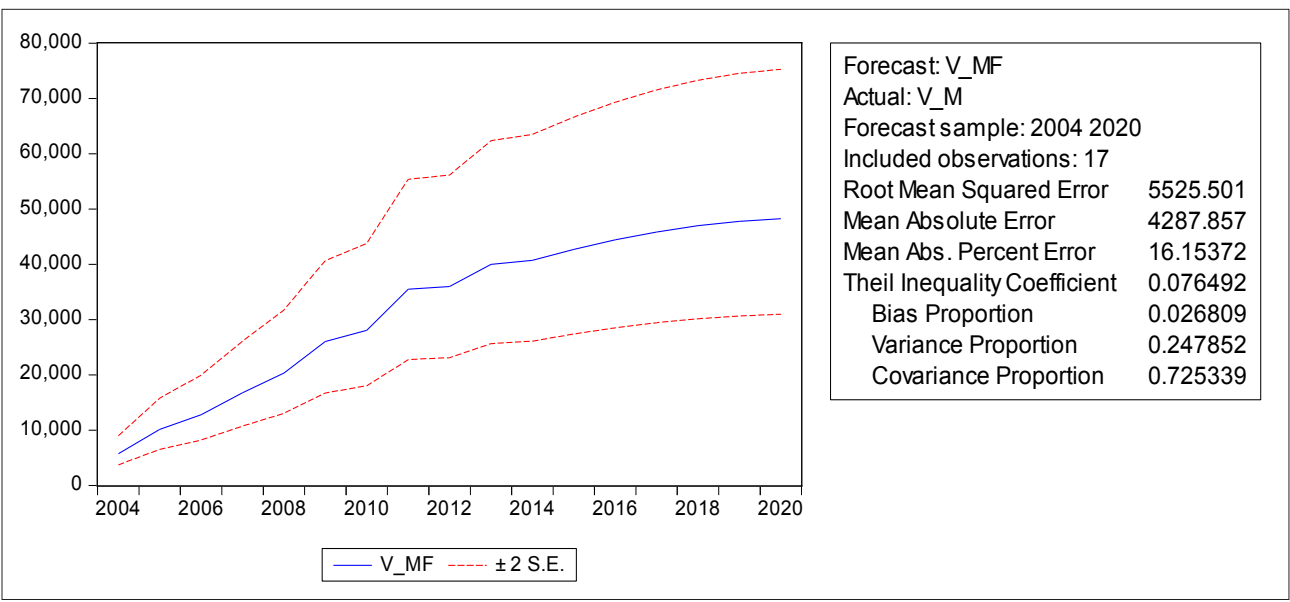

Fig. 2. Forecast of agriculture products production for enterprise A, thsd UAH

Source: calculated by the author

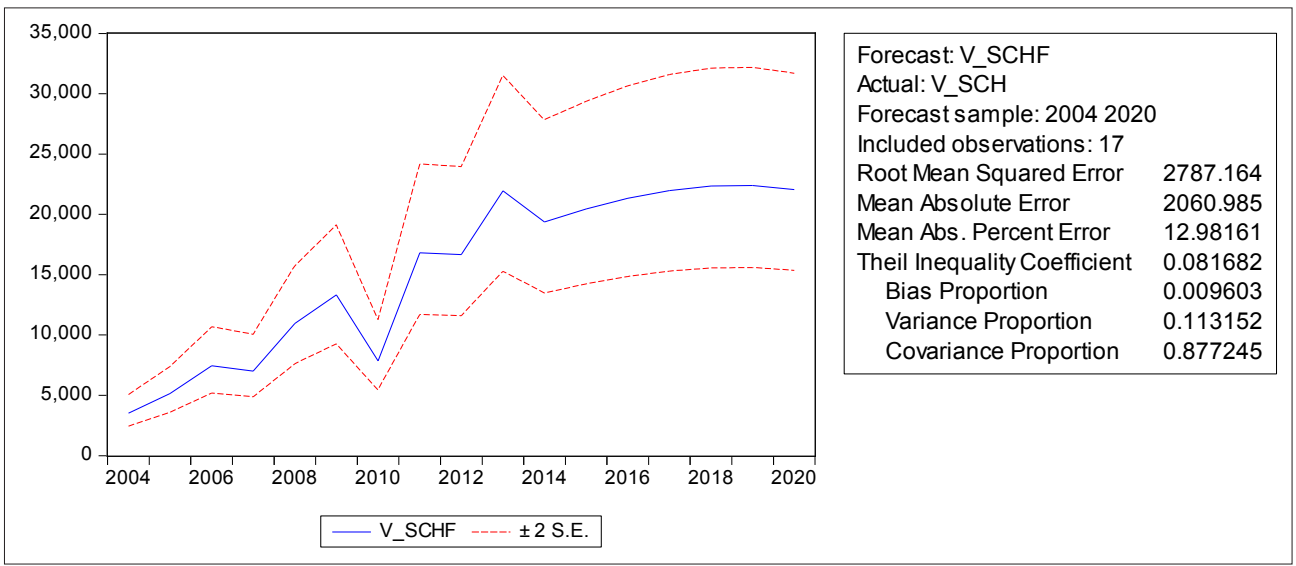

Fig. 2. Forecast of agriculture products production for enterprise B, thsd UAH

Source: calculated by the author 
the enterprise A it's $\mathrm{L}=0,74$ and $\mathrm{K}=0,12$ as well as for the enterprise $B$ it's $L=0,85$ and $K=0,48$. High determination coefficient for these companies shows that labour and capital influence on production volume at $85 \%$ for the enterprise $A$ and at $95 \%$ for the enterprise B. Forecasts for both enterprises indicate that there is high probability level for production volume increase in future which mean necessity in infrastructure investments and search of the new distribution channels. At the same time, for achieving this growth it's reasonable to invest in equity not in labour for improving competitiveness of Ukrainian agricultural enterprises in long-term period.

\section{References}

Say, J.-B. (2012). A Treatise on Political Economy. - London, Forgotten Books, 494 p.

Smith, A. (2012). The Wealth of Nations. - London, Simon \& Brown, 544 p.

Shumska, S.S. (2007). The instrument of production function in Ukrainian economy research. - Economics and forecasting, Vol. 4: 104-123.

Shepherd, R.W. (2015). Theory of Cost and Production Functions. - Princeton, Princeton University Press, 322 p. Shumska, S.S. (2007). Production function in economic analysis: theory and practice of usage. - Economics and forecasting, Vol. 2: 138-153.

Kundyzky, O.O. (2012). Economic regulation of inputs reproduction. - Sumy, Dovkillya publishing, 344 p.

Mocherny, S.V. (2005). Economic encyclopedic dictionary. - Lviv, Svit publishing, 616 p.

\section{Сергей УС}

\section{ОЦЕНКА ПРОИЗВОДСТВЕННОЙ ДЕЯТЕЛЬНОСТИ И РАЗВИТИЕ СЕЛЬСКОХОЗЯЙСТВЕННЫХ ПРЕДПРИЯТИЙ УКРАИНЫ}

Аннотация. Целью статьи есть анализ соотношения между объемом производства (V), фактором труда (L) и фактором капитала (K) с последующим прогнозом объема производства исследованных сельскохозяйственных предприятий в Украине, а также их конкурентоспособность на Европейском рынке. Методика. Исследование основано на статистической информации государственной службы статистики Украины, Польши и бухгалтерской отчетности исследованных предприятий в период 20042013 годов. Производственный объем и капитал взяты в денежном выражении, фактор труда рассчитан в денежном выражении с помощью показателей средней заработной платы и количества работников. Обобщена трактовка основных производственных факторов в соответствии с классической экономической теорией. Корреляция факторов V, L и K рассчитана с помощью метода наименьших квадратов через оценку производственной функции. Спрогнозировано объем производства предприятий А и В с последующей оценкой его достоверности в эконометрической программе EViews 7. Результаты исследования отображают доминирующую роль фактора труда над фактором капитала, особенно после экономического кризиса 2008 года в исследованных сельскохозяйственных предприятиях Украины. Высокий коэффициент детерминации указывает на влияние обоих факторов на объем производства на уровне $85 \%$ для предприятия А и $95 \%$ для предприятия В. Прогноз производства демонстрирует увеличение его объема в обоих предприятиях с высокой вероятностью в соответствии с индикатором достоверности прогноза МАРЕ. Практическое значение. Применение полученных результатов, в частности соотношения факторов производства и прогноза его объема, позволит эффективнее использовать производственные ресурсы и точнее планировать производственный процесс в соответствии с конъюнктурой рынка. Значение/оригинальность. Оценка производственной деятельности и прогноз результатов производства исследованных предприятий использованы для сравнения конкурентоспособности сельскохозяйственных предприятий Украины и Польши, что важно в условиях процесса европейской интеграции отечественной экономики. 